\title{
Simultaneous Determination of Three Phenolic Compounds in Water Samples by Pre-column Derivatization Coupled with Reversed-Phase High Performance Liquid Chromatography
}

\author{
Üç Fenolik Bileşiğin Kolon Öncesi Türevlendirme ile Ters-Faz Sıvı \\ Kromatografisi Yöntemi Kullanılarak Su Örneklerinde Eşzamanlı \\ Tayini \\ Research Article
}

\author{
Adem Asan ${ }^{1 *}$, M. Umut Konanc ${ }^{2}$, Bediha Akmese ${ }^{3}$ \\ 'Ondokuz Mayis University, Faculty of Science, Department of Chemistry, Kurupelit-Samsun, Turkey. \\ ${ }^{2}$ Artvin Coruh University, Research laboratory, Artvin, Turkey. \\ ${ }^{3}$ Hitit University, Faculty of Science, Department of Chemistry, Corum, Turkey.
}

\section{A B S TR ACT}

\begin{abstract}
In this study, a sensitive and accurate method for simultaneous separation and determination of three phenolic compounds (phenol, m-cresol and resorcinol) in water by revesed-phase high performance liquid chromatography using uv-visible detection has been described. Pre-column derivatization with 4-aminoantipyrine is used for the seperation and determination phenol, $\mathrm{m}$-cresol and resorcinol in water. The derivatives formed within 5 min were extracted with chloroform and then analyzed by liquid chromatography with UV-visible detection at $440 \mathrm{~nm}$. Chromatographic separation was performed using a reversed-phase column and acetonitrile-water (45:55\%,v/v) as the mobile phase. The three derivatives were elueted in $13 \mathrm{~min}$. The detection limits of phenol, $\mathrm{m}$-cresol and resorcinol in a standard water sample were between 0.07 and 0.09 $\mu \mathrm{g} . \mathrm{L}^{-1}$ for $100 \mathrm{~mL}$ respectively. The recoveries of the derivatives from pure water were between $97.1-102.3 \%$ within relative standard deviations of $2.3-4.7 \%$. The method was applied to the analysis of phenols in different water samples.
\end{abstract}

\section{Key Words}

Phenols, derivatization, reversed-phase liquid chromatography, 4-aminoantipyrine.

\section{öz}

u çalışmada; suda üç fenolik bileşiğin (fenol, m-kresol ve resorsinol), UV-görünür detektör kullanılarak ters-faz yüksek performanslı sıvı kromatografisi ile ayrılması ve eş zamanlı tayini için hassas ve doğru bir yöntem geliştirildi. Fenol, m-krezol ve resorsinolün sudaki tayini ve ayrılması için kolon öncesi 4-aminoantipirin ile türevlendirilmiştir. 5 dakika içinde oluşan türevler kloroform ile ODS kolondan geri alınmıştır ve daha sonra 440 nm'de UV-görünür detektörde sıvı kromatografisi ile analiz edilmiştir. Kromatografik ayırım, tersfaz kolonda ve mobil faz olarak asetonitril-su (\%45:55, v/v) karışımı kullanılarak gerçekleştirilmiştir. Üç fenol türevi 13 dakikada içerisinde başarıyla ayrılmıştır. Standart bir su numunesinde fenol, $\mathrm{m}$-kresol ve resorsinolün tayin sınırı sırasıyla $100 \mathrm{~mL}$ için 0.07 ve $0.09 \mu \mathrm{g} . \mathrm{L}^{-1}$ arasındadır. Türevlerin saf sudan geri kazanımı, \%2.34.7'lik bağıl standart sapma ile \%97.1-102.3 düzeylerinde bulundu. Yöntem, farklı su numunelerindeki fenollerin analizi için başarıyla uygulandı.

\section{Anahtar Kelimeler}

Fenoller; türevlendirme, ters faz sıvı kromatografisi; 4-aminoantipirin. 


\section{INTRODUCTION}

henolic compounds are toxic substances that occur naturally in the environment, in plants and food [1]. Therefore, these compounds are typically found in domestic and industrial products, natural waters and potable water supplies. Owing to their toxicity, persistence and unpleasant organoleptic properties [2,3], both the US Environmental Protection Agency (EPA) and the European Union (EU) have classified several phenols as priority pollutant [4].

They have also been employed as raw materials for drugs, pesticides, synthetics fibers, resins, and dyes. Thus, they are discharged from a variety of industrial plants to environmental water. Their input into the ecosystems results directly from human activity or indirectly from the transformation of natural or synthetic chemicals and they are found in waters from various sources [5-8]. Several methods have been reported for the determination of phenolic compounds in different samples including spectrophotometric methods [9], high-performance liquid chromatography (HPLC) [10-17] gas chromatography (GC) [18-23] and capillary electrophoresis [24,25]. Owing to the complex nature of samples (biological, water, etc) and low concentration of phenolic compounds in such samples, their isolation and preconcentration are commonly necessary prior to their quantitative determination. Liquid-liquid extraction [26] and solid-phase extraction [27] are the most usual techniques for this purpose.

In this study, a sensitive and accurate method for simultaneous separation and determination of three phenolic compounds (phenol, m-cresol and resorcinol) in water by reversed-phase high performance liquid chromatography using UV-visible detection has been established. The main objective of this study is to develop and validate a selective and sensitive method for the simultaneous determination of phenolic compounds in water. A reversed-phase liquid chromatographic and UV-visible detection was accomplished based on pre-column the reaction between phenols and 4-aminoantipyrine (4-AA). 4-AA is a common reagent and that has been previously studied [28]. Although in the present study, the derivatization reaction between 4-AA and phenolic compounds were modified in the presence of potassium peroxydisulfate as oxidizer. Then obtained derivatives (quinoneimines) exhibited intense absorption at $440 \mathrm{~nm}$ were separated in RP-HPLC system and determined using visible spectrophotometric detector. Consequently, a simple pre-column derivatization plus reversed-phase liquid chromatographic procedure for the determination of phenolic compounds in water at ppb levels was obtained.

\section{MATERIALS and METHODS}

\section{Reagents and Chemicals}

The phenolic compounds (phenol, m-cresol and resorcinol) and the derivatization agent (4-aminoantipyrine) (4-AA) were obtained from Sigma-Aldrich. The tested extraction solvents were purchased from Merck. All other reagents were of analytical reagent grade and were used without further purification. Individual standard phenol stock solutions $\left(500 \mathrm{mg} \cdot \mathrm{L}^{-1}\right)$ were prepared by dissolving $50 \mathrm{mg}$ of phenol in $100 \mathrm{~mL}$ of deionized water. Working standard solutions of various concentrations were prepared daily by diluting the stock solution with deionized water. Ultrapure Milli-Q water (Millipore) was used for the preparation of solutions. The stock solutions were stable for up to 2 week when stored in the dark at room temperature. The 4-aminoantipyrine stock solution (88 $\mathrm{mmol}^{-1}$ ) was prepared by dissolving $1.8 \mathrm{~g}$ of 4 -aminoantipyrine in $100 \mathrm{~mL}$ of deionized water.

The ammonia buffer solution was prepared by dissolving $6.75 \mathrm{~g}$ of ammonium chloride in $57 \mathrm{~mL}$ of ammonia and diluted to $100 \mathrm{~mL}$ with deionized water. An ammonium peroxodisulfate stock solution ( $88 \mathrm{mmol} . \mathrm{L}^{-1}$ ) of $\mathrm{pH} 10$ was prepared by dissolving $2.0 \mathrm{~g}$ of ammonium peroxodisulfate in $80 \mathrm{~mL}$ of water, while adjusting to $\mathrm{pH} 10$ by the addition of a potassium hydroxide solution (2 mol. $\mathrm{L}^{-1}$ ) and diluting to $100 \mathrm{ml}$ of water.

The water samples (Borcka dam lake and Murgul stream) were collected (in 1-1 dark colored glass bottles) from the Artvin in Turkey. The area where the samples are taken was the place where 
the garbage is laid and near to the mine site. The bottles were previously washed with $0.1 \mathrm{~mol}^{-1}$ $\mathrm{HCl}$ and repeatedly rinsed with deionized water. During sampling, the bottles were rinsed twice with the sample water, then filled and tightly capped. Samples were filtered through Millipore membrane filters $(0.45-\mu \mathrm{m}$ pore size, Millipore, Bedford, USA) and analyzed immediately.

\section{Apparatus}

Chromatographic analysis was performed using a Shimadzu liquid chromatograph LC-20AD (Kyoto, Japan), equipped with binary solvent delivery units (LC-2OAD), UV-vis detector (SPD- M20A), LC solution Version 1.25 and an auto sampler (SIL20 MT). The LC solution workstation software was used to control the gradient setting and data acquisition.

Absorbance measurements for phenol derivatives were performed using a UV-visible spectrophotometer (Shimatzu UV-1800, Tokyo, Japan). For $\mathrm{pH}$ measerements, the $\mathrm{pH}$ meter (WTW ino lab $\mathrm{pH}$ level 1) with a $\mathrm{pH}$-electrode Sentix-41 was used.

A GL Sciences Inertsil ODS-2 C18 reversedphase column $(250 \mathrm{~mm} \times 4.6 \mathrm{~mm}, 5 \mu \mathrm{m}$ particle size) was used for the separation of the target analysts. Mobile phase composition that providing the best separation was a mixture acetonitrile and water $(45: 55 \%, v / v)$, which was filtered and degassed prior to use. The flow-rate was $1.0 \mathrm{~mL} /$ min, the sample injection volume was $20 \mu \mathrm{L}$, and the detection wavelength was $440 \mathrm{~nm}$.

\section{Derivatization and Extraction Procedure}

The 4-aminoantipyrine (4-AA) derivatives of the phenols were prepared according to the procedure described by Morita and Nakamura [28], after a major modification. To a $100 \mathrm{~mL} 1 \times 10^{-4} \mathrm{~mol}^{-\mathrm{L}^{-1}}$ each phenolic compound solution, $5 \times 10^{-4} \mathrm{~mol}^{-1}$ of $4-A A$ and $5 \times 10^{-4}$ mol. $^{-1}$ of potassium peroxydisulfate $\left(\mathrm{K}_{2} \mathrm{~S}_{2} \mathrm{O}_{8}\right)$ were added.

The mixture was alkalinized to $\mathrm{pH} 9$ using 0.1 $\mathrm{M}$ ammonia/ammonium buffer solution which was added dropwise under vigorous shaking for $5 \mathrm{~min}$. The reaction is as shown in Figure 1. The thusprepared solution was left standing for $5 \mathrm{~min}$ at room temperature, and then both solid-liquid and liquid-liquid extraction procedures were applied to collect the quinoneimine derivatives obtained as a result of the reaction. The derivatization reaction is shown in Figure 1.

For the solid-phase extraction, the solution was passed through the ODS-functionalized silica cartridge (60x8 mm constructed in the laboratory), which was washed with $5 \mathrm{~mL}$ of methanol and $10 \mathrm{~mL}$ of deionized water subsequently before use. The adsorbed quinoneimine derivatives were eluted with $2 \mathrm{~mL}$ of different extraction solvents (chloroform, hexane, dichloromethane and diethyl ether). For the liquid-liquid extraction, extraction efficiencies were compared by adding different extraction solvents onto the phenol derivatives solution. The highest extraction yield was obtained using chloroform. The samples were extracted with $1 \times 10 \mathrm{~mL}$ and $1 \times 5 \mathrm{~mL}$ of chloroform. The water layer was saved and potassium chloride
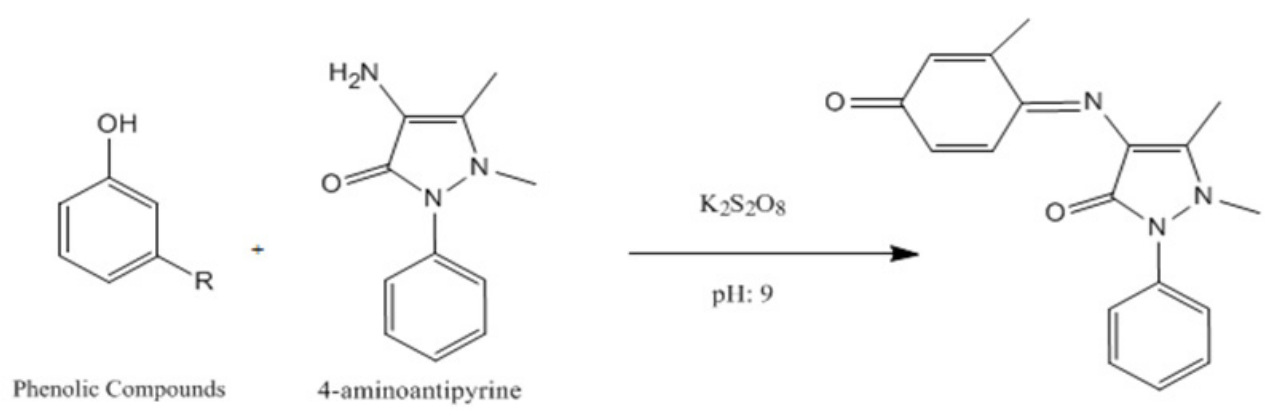

Quinoneimine Derivatives

Figure 1. Derivatization reaction between phenol compounds and 4-aminoantipyrine. 
$(1.2 \mathrm{~g})$ added to increase the ionic strength and promote the transfer of quinoneimine derivatives into the organic extract. For all extractions, separating funnels were shaken for $1 \mathrm{~min}$ and the phases were allowed to separate for $3 \mathrm{~min}$. The extracts were evaporated to dryness at $40^{\circ} \mathrm{C}$ in a water bath. The precipitates were redissolved in $1 \mathrm{~mL}$ of mobil phase (acetonitrile and water $45: 55, v / v)$ and $20 \mu \mathrm{L}$ of each sample was injected onto the RP-HPLC system. In applications of the method, a sample volume of a $100 \mathrm{~mL}$ was used for the extraction, since a reasonable linearity was obtained for all phenols studied. The phenols were identified from their retention times and quantitatively determined their peak areas.

\section{RESULTS and DISCUSSION}

\section{Optimization of the derivatization reaction}

As the derivatization reaction of phenolic compounds with 4-aminoantipyrine proceeded in a basic medium, the effect of the $\mathrm{pH}$ in the presence of ammonia/ammonium buffer solution was examined using a standard solution of the phenols at a concentration of $1 \times 10^{-4} \mathrm{~mol} . \mathrm{L}^{-1}$. The peak heights of all compounds reached maxima at $\mathrm{pH}$ 8-10. The highest peak height was obtained at $\mathrm{pH}$ 9. For this reason, the $\mathrm{pH}$ value was 9 throughout the study. The effect of peak height with $\mathrm{pH}$ change is shown in Figure 2.

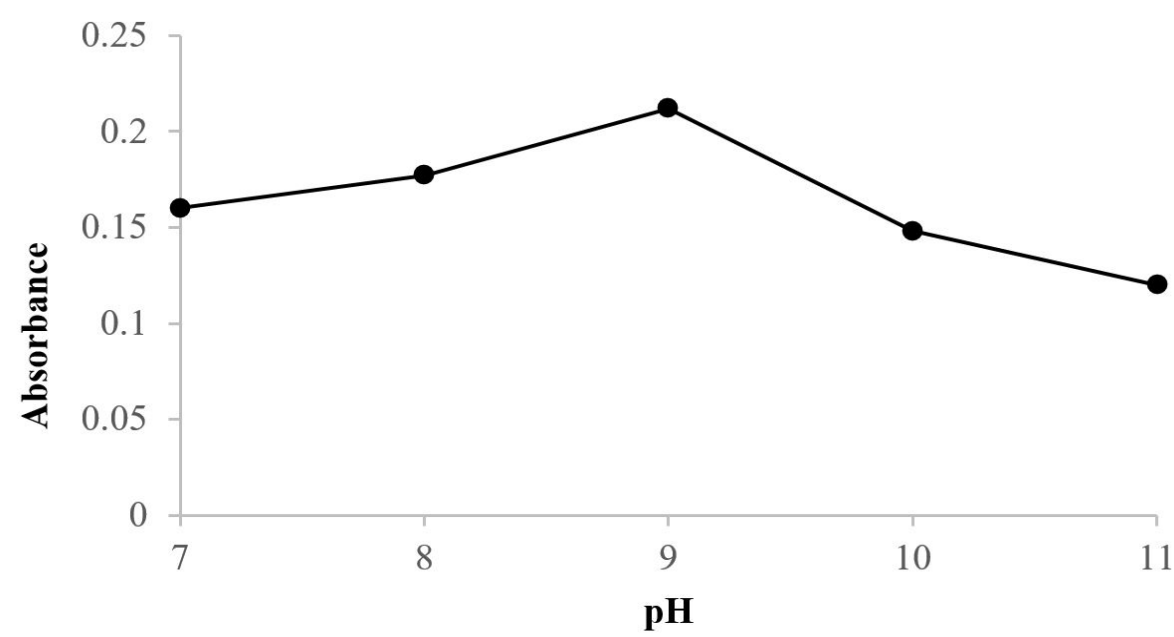

Figure 2. Effect of $\mathrm{pH}$ on the derivatization reaction between phenol compounds and 4-aminoantipyrine (phenol: $1 \times 10^{-4} \mathrm{M}$; peroxydisulfate: $5 \times 10^{-4} \mathrm{M}$; 4-aminoantipyrine: $5 \times 10^{-4} \mathrm{M}$ ).

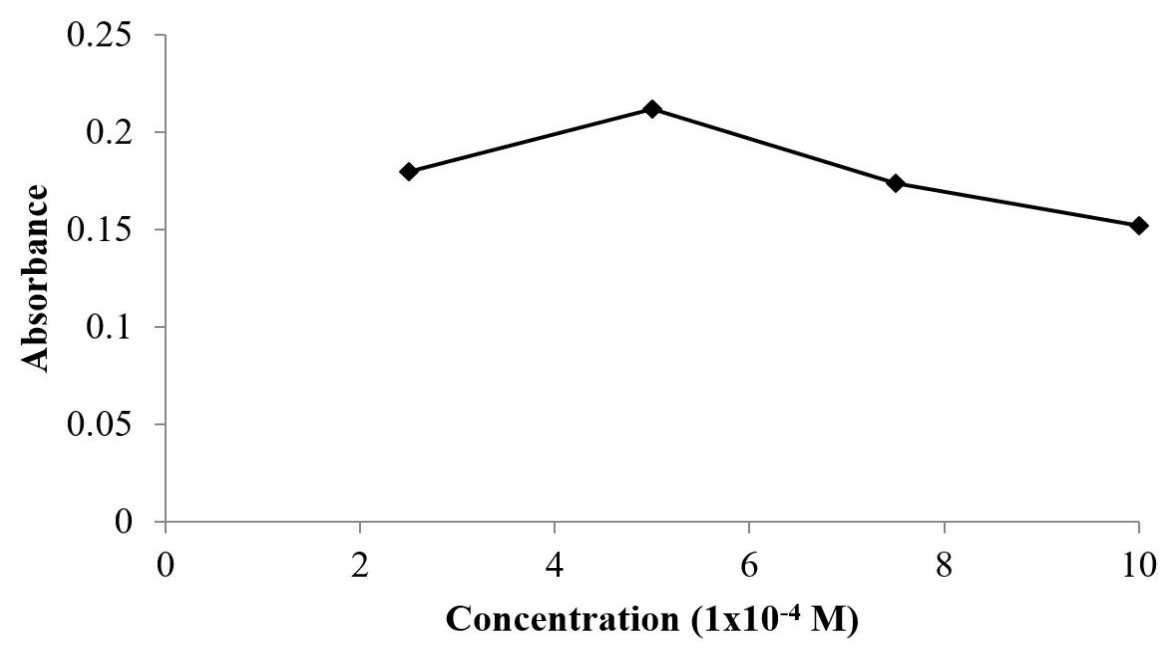

Figure 3. Effect of 4-aminoantipyrine concentration on the derivatization reaction (phenol: $1 \times 10^{-4} \mathrm{M}$; peroxydisulfate: $\left.5 \times 10^{-4} \mathrm{M}\right)$. 
The effect of 4-aminoantipyrine concentrations on the reaction was tested. The highest absorption value was obtained when 4-aminoantipyrine was used at a concentration of $5 \times 10^{-4}$ mol. $L^{-1}$. The effect of absorption with 4-aminoantipyrine concentration change is shown in Figure 3.

The amount of peroxydisulfate $\left(\mathrm{K}_{2} \mathrm{~S}_{2} \mathrm{O}_{8}\right)$ used as oxidant in the reaction was tested. It was determined that the optimum amount of peroxydisulfate for the derivatization reaction was $5 \times 10^{-4}$ mol. $L^{-1}$. The effect of absorption with peroxydisulfate concentration change is shown in Figure 4.
Temperatures of 30,40 and $50^{\circ} \mathrm{C}$ were tested. All peak heights reached a maximum after a reaction time 10 min at all temperatures. For this reason, the work was done at room temperature. Figure 5 shows the effect of temperature on peak height. As a result, all the parameters in the reaction are optimized.

\section{Calibration, Detection Limits and}

\section{Repeatability}

Calibration graphs were performed using the external standard technique following.Linear regression analysis by plotting concentration ( $\left.\mu \mathrm{g} . \mathrm{L}^{-1}\right)$ against peak area. Table 1 shows the

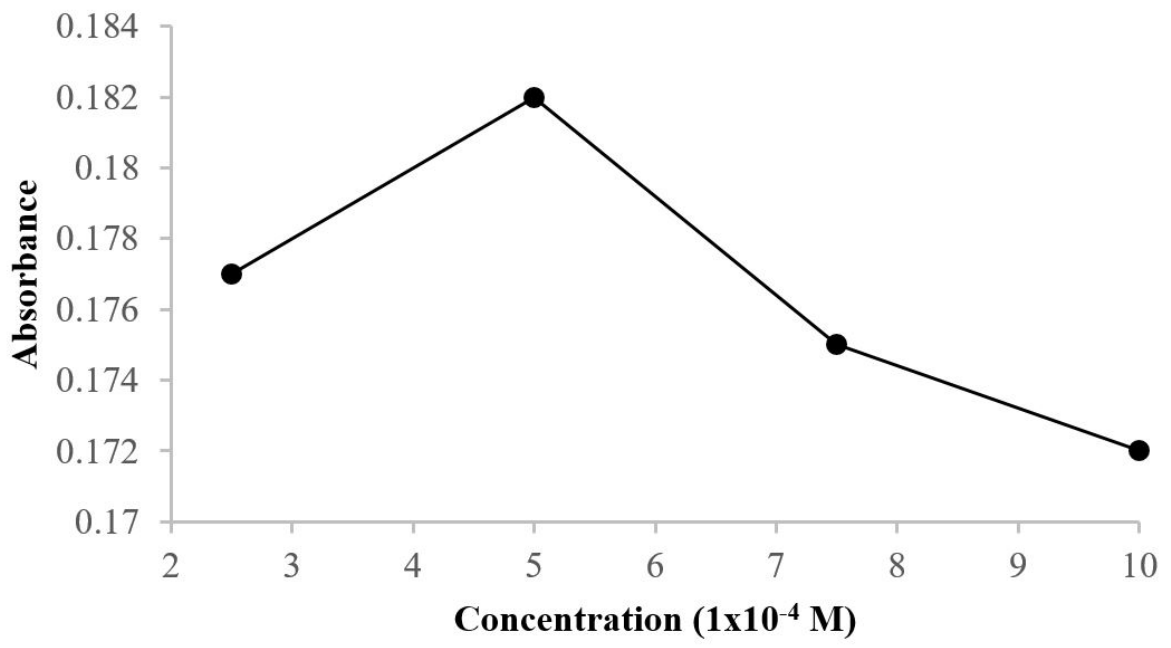

Figure 4. Effect of peroxydisulfate concentration on derivatization reaction (phenol: $1 \times 10^{-4} \mathrm{M} ; 4$-aminoantipyrine: $5 \times 10^{-4} \mathrm{M}$ ).

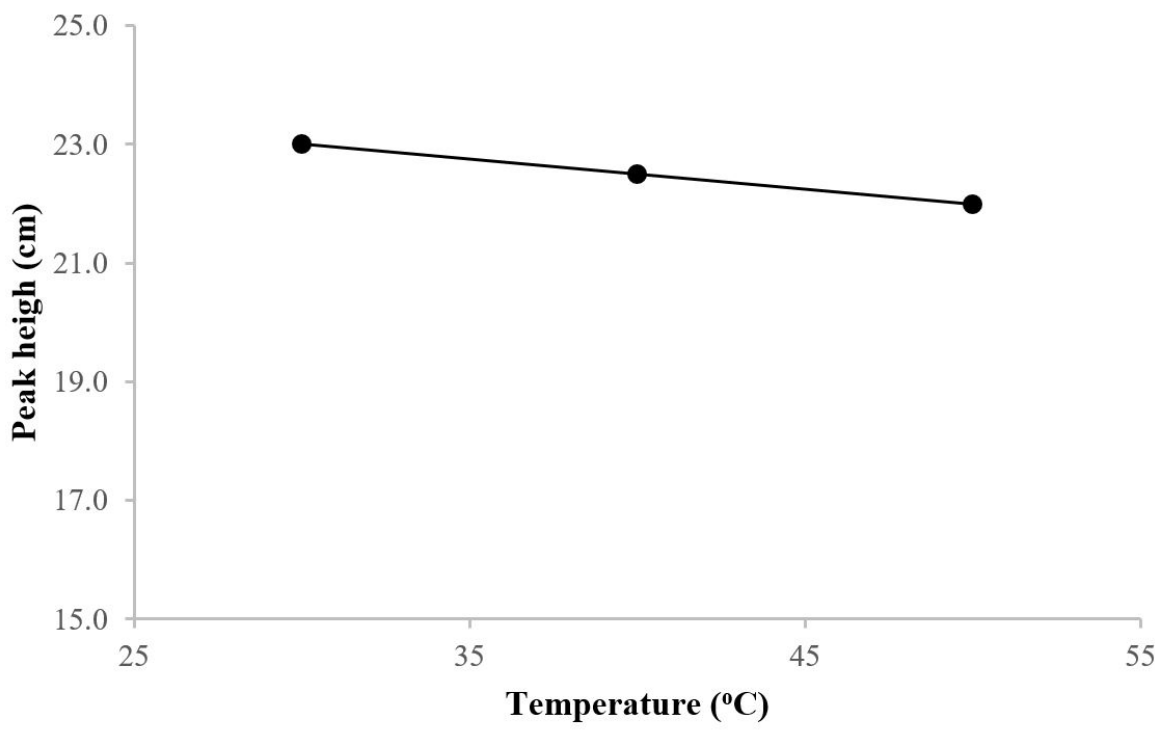

Figure 5. Effect of temperature on peak height. 
equations obtained fort the calibration graphs and the regression coefficients. The repeatability of the method was calculated using the average relative standard deviation (RSD) for 10 replicate injections of the same sample at $10 \mu \mathrm{g} . \mathrm{L}^{-1}$. The reproducibility was calculated using the RSD. For 10 injections of the same sample $\left(10 \mu \mathrm{g} . \mathrm{L}^{-1}\right)$ on different days. The LOD and LOQ were calculated using the standard deviation (s) of response and the slope $(\mathrm{m})$ of the calibration curve as $L O D=3.3$ $\mathrm{s} / \mathrm{m} ; \mathrm{LOQ}=10 \mathrm{~s} / \mathrm{m}$ [29-31]. All values obtained are given in Table 1. precision and accuracy for intraday and inter-day assays of these derivatives are shown in Table 2. In the intra-day assay, the range of standard deviation for retention time was within 0.23 to $0.39 \%$ and standard deviation for peak area was within 2.17 to 3.73 . In the inter-day assay, the range of standard deviation for retention time was within 0.26 to $0.41 \%$ and standard deviation for peak area was within 2.66 to $3.68 \%$. Figure 6 shows the standard chromatogram of derivatives of phenol compounds.

\section{Recovery}

Both liquid-solid and liquid-liquid extraction were carried out for the extraction of quinoneimine derivatives. It was determined that the best extraction method for these derivatives was liquid-liquid extraction. For this reason, liquidliquid extraction method was used for isolating the derivatives. Different solvents (chloroform, hexane, dichloromethane and diethyl ether) were used for extraction. Chloroform was chosen as the best among them. Extraction of quinoneimine derivatives with chloroform resulted a substantial improvement enabling a high recovery for the phenolic compounds from Murgul stream water and Borcka Dam Lake.

The efficiency of the extraction procedure and the recovery of phenols from $100 \mathrm{~mL}$ of Murgul stream water and Borcka Dam Lake are shown in Table 3 and Table 4. At the same time, Tables also show repeatability and reproducibility. For the Murgul stream water, the quantities of phenols were spiked to different concentrations and over $97.1-102.3 \%$ of the phenols was recovered from water with relative standard deviations 2.34.7\% and also Borcka Dam Lake, the quantities of phenols were spiked to different concentration and over $97.4-103.1 \%$ of the phenols was recovered from water with relative standard deviations $2.3-4.1 \%$.

\section{Applications}

The described method was used to determine phenol, m-cresol and resorcinol in tap water and water samples. As shown in Table 5, the level of phenol, $\mathrm{m}$-cresol and resorcinol in tap water was below the lower limit of quantification. In Table 5,

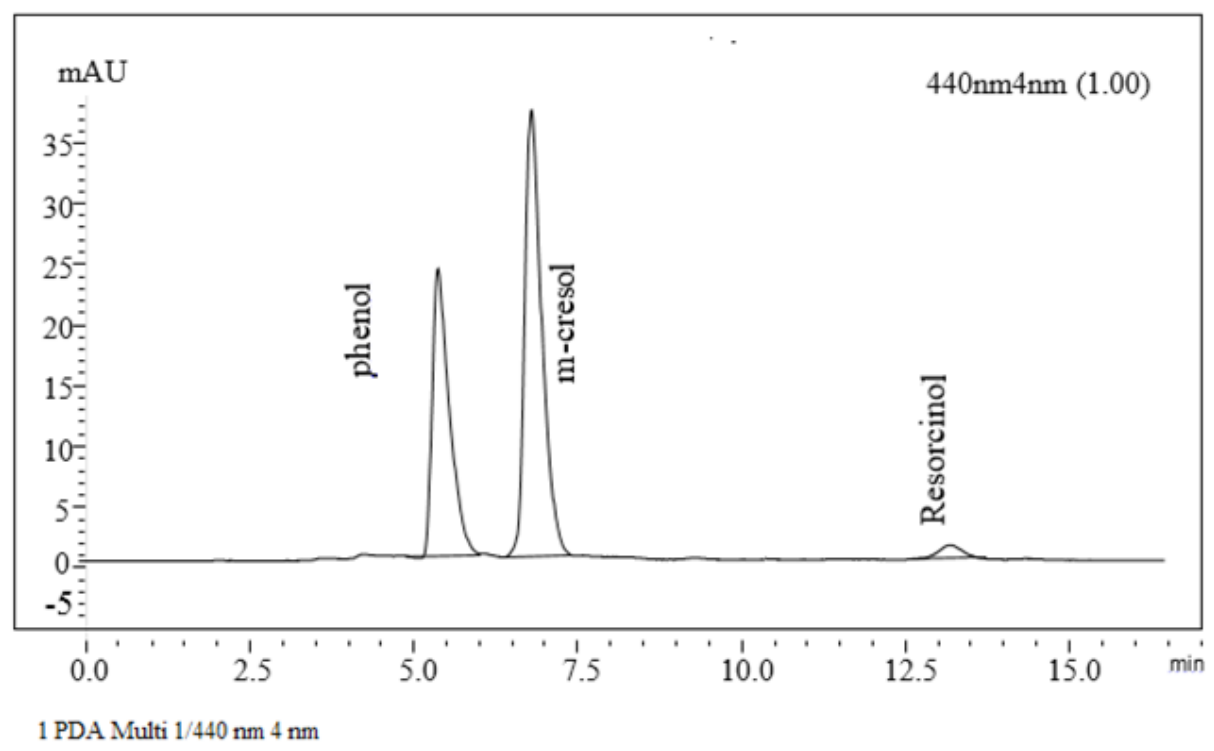

Figure 6. Reversed-phase HPLC-UV-vis. chromatograms of quinoneimine derivatives of phenols. Phenol, $6.0 \mathrm{ng}$; m-cresol, 7.4 ng; resorcinol, 2.0 ng. Column: GL Science Inertsil C 18 RP ( $5 \mu \mathrm{m}, 250 \mathrm{~mm}$ x $4.6 \mathrm{~mm}$ ID). Mobil phase: acetonitrile-water (45:55\%, v/v); Flow-rate: $1.0 \mathrm{~mL} \mathrm{~min}^{-1}$. 
Table 1. Retention time $\left(t_{R}\right)$ and linear regression parameters, LOD and LOQ, of the determined phenolic compounds.

\begin{tabular}{lcccccc}
\hline Analyte & $\begin{array}{c}\mathrm{t}_{\mathrm{R}} \\
(\mathrm{min})\end{array}$ & Calibration curve & \multicolumn{1}{c}{$\begin{array}{l}\text { Linearity } \\
\text { range } \\
\left(\mu \mathrm{g} . \mathrm{L}^{-1}\right)\end{array}$} & $\begin{array}{l}\mathrm{LOD} \\
\left(\mu \mathrm{g} . \mathrm{L}^{-1}\right)\end{array}$ & $\begin{array}{c}\mathrm{LOQ} \\
\left(\mu \mathrm{g} . \mathrm{L}^{-1}\right)\end{array}$ \\
\hline phenol & 6.1 & $\mathrm{y}=62.821 \mathrm{x}+7067$ & 0.9968 & $5.0-250$ & 0.07 & 0.31 \\
\hline m-cresol & 7.2 & $\mathrm{y}=58.374 \mathrm{x}+5535$ & 0.9995 & $10-300$ & 0.08 & 0.35 \\
\hline resorcinol & 12.6 & $y=73.811 x-3052$ & 0.9988 & $2.0-100$ & 0.09 & 0.38 \\
\hline
\end{tabular}

Table 2. Precision of three phenolics for retention time $\left(t_{R}\right)$ and peak area $(p a)(n=5)$.

\begin{tabular}{lllll}
\hline Analyte & Intra-day variations & \multicolumn{3}{c}{ Inter-day variations } \\
\hline RSD for $t_{R}(\%)$ & RSD for pa (\%) & RSD for $t_{R}(\%)$ & RSD for pa (\%) \\
\hline phenol & 0.23 & 2.17 & 0.26 & 3.56 \\
\hline m-cresol & 0.33 & 2.67 & 0.38 & 2.66 \\
\hline resorcinol & 0.39 & 3.73 & 0.41 & 3.68 \\
\hline
\end{tabular}

Table 3. Summary of results from analysis of phenols in spiked $100 \mathrm{~mL}$ of Murgul stream water $(n=5)$.

\begin{tabular}{lccccc}
\hline \multirow{2}{*}{ Analyte } & $\begin{array}{c}\text { Amount } \\
\text { added (ng) }\end{array}$ & $\begin{array}{l}\text { Recovery } \\
\text { (\%) }\end{array}$ & $\begin{array}{c}\text { RSD } \\
(\%)\end{array}$ & $\begin{array}{c}\text { Repeatability } \\
\text { RSD (\%) }\end{array}$ & $\begin{array}{c}\text { Reproducibility } \\
\text { RSD (\%) }\end{array}$ \\
\hline 10 & 98.7 & 2.4 & 1.7 & 2.3 \\
\hline m-cresol & 200 & 102.3 & 2.3 & & \\
\hline & 20 & 99.3 & 3.5 & 1.9 & 2.5 \\
\hline resorcinol & 150 & 98.1 & 2.9 & & \\
\hline & 250 & 101.2 & 3.2 & & \\
\hline & 50 & 98.3 & 3.1 & 2.5 & \\
\hline
\end{tabular}

the results for the water samples are given. The concentration of phenolic compounds in different water samples were successfully determined. In Figure 7 and 8 typical chromatograms of phenols in $100 \mathrm{~mL}$ of Murgul stream and Borcka Dam Lake water samples are shown. Obviously, low ng. $\mathrm{mL}^{-1}$ levels of phenols can be successfully determined in environmental samples. As Table 5 shows, phenolic compounds could not be assigned to tap water. The maximum amount of $m$-cresol was found in the Borcka Dam Lake water. On the other hand, the amount of resorcinol is the most in the Murgul stream water.

The comparison of the new method and reported methods (published over the period 2001-2016) is presented in Table 6. The proposed method without complex pre-treatment offered the linear range is $2-300 \mu \mathrm{g} . \mathrm{L}^{-1}$ and LOD is 0.07 $\mu \mathrm{g} . \mathrm{L}^{-1}$ for phenolic compounds, which were significantly lower than the reported methods in Table 6. 
154 A. Asan et al. / Hacettepe J. Biol. \& Chem., 2018, 46 (2), 147-157

Table 4. Summary of results from analysis of phenols in spiked $100 \mathrm{~mL}$ of Borcka dam lake water $(n=5)$.

\begin{tabular}{lccccc}
\hline \multirow{2}{*}{ Analyte } & Amount added & Recovery & RSD & Repeatability & Reproducibility \\
\hline phenol & $(\mathrm{ng})$ & $(\%)$ & $(\%)$ & RSD (\%) & RSD (\%) \\
\hline 10 & 97.7 & 2.3 & 1.9 & 2.1 \\
\hline m-cresol & 100 & 98.6 & 2.7 & & 2.3 \\
\hline & 200 & 102.9 & 2.6 & 3.4 & 2.8 \\
\hline resorcinol & 90 & 97.8 & 3.1 & & 2.1 \\
\hline & 150 & 102.5 & 3.4 & & 2.1 \\
\hline
\end{tabular}

Table 5. Analytical results of water samples from different locations*.

\begin{tabular}{llcccc}
\hline \multirow{2}{*}{ Analyte } & $\begin{array}{l}\text { Tap } \\
\text { water }\end{array}$ & Borcka dam water** & & Murgul stream water** \\
& & $\bar{X}$ & ts & $\bar{X}$ & ts \\
\hline phenol & ND & 7.6 & 2.3 & 9.8 & 2.9 \\
\hline m-cresol & ND & 11.2 & 3.8 & 12.9 & 4.1 \\
\hline resorcinol & ND & 8.5 & 2.9 & 17.3 & 3.2 \\
\hline
\end{tabular}

*Samples were collected at Artvin, Turkey.

**Values represent the average $\left(=\mu \mathrm{g} . \mathrm{L}^{-1}\right)$, standard deviation (ts $\left.=\%\right)$, for $\mathrm{n}=5$ with a confidence of $95 \%$. ND: Not detected

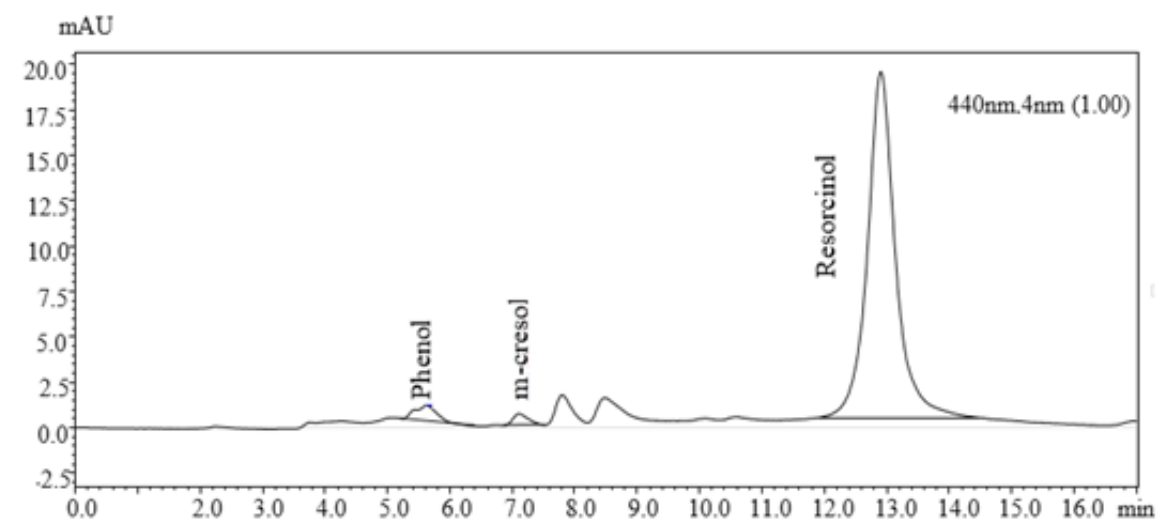

1 PDA Multi $1 / 440 \mathrm{~nm} 4 \mathrm{~nm}$

Figure 7. Reversed-phase HPLC-UV-vis. chromatograms of quinoneimine derivatives of phenols obtained from 100 $\mathrm{mL}$ of Murgul stream water. For conditions and peak assignment, see Figure 2. 


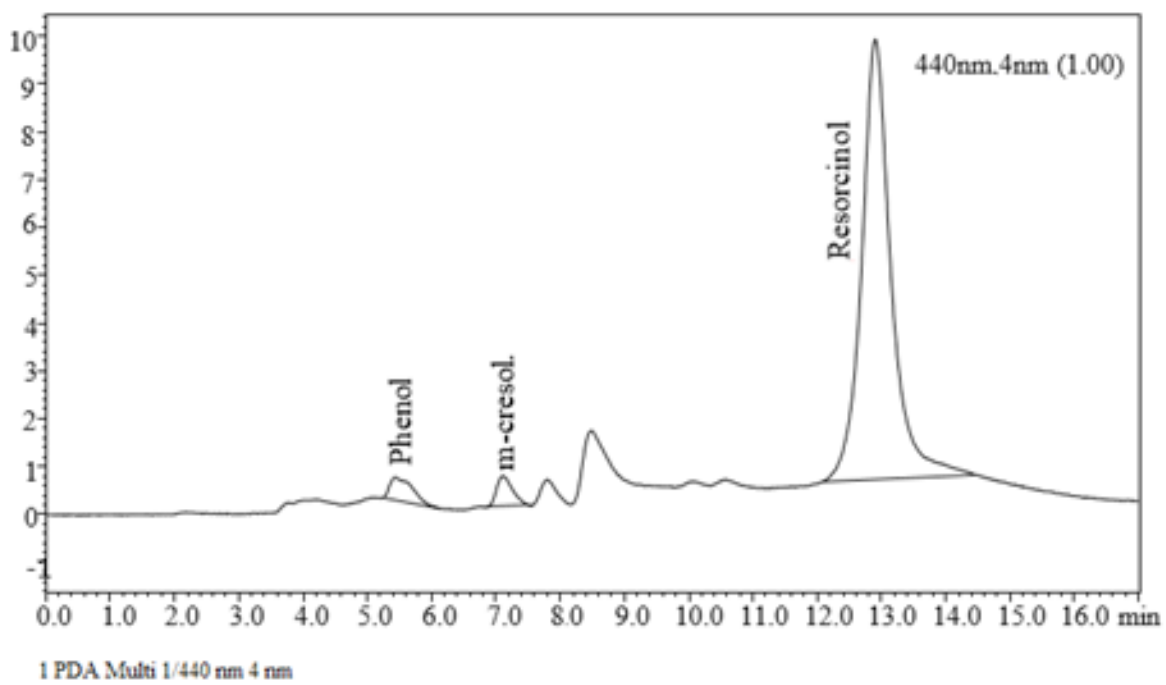

Figure 8. Reversed-phase HPLC-UV-vis. chromatograms of quinoneimine derivatives of phenols obtained from 100 $\mathrm{mL}$ of Borcka dam lake water. For conditions and peak assignment, see Figure 2.

Table 6. Comparison of literature HPLC methods (published over the period 2001-2016) for proposed method and some reported procedures for phenolic compound determination.

\begin{tabular}{|c|c|c|c|c|}
\hline Method & Sample & Linear renge & Limit of detection & Reference \\
\hline HPLC-UV & Aqueous sample & $0.5-2.5 \mu \mathrm{g} . \mathrm{L}^{-1}$ & $0.05 \mu \mathrm{g} . \mathrm{L}^{-1}$ & $\begin{array}{l}\text { Zhao and Lee, } 2001 . \\
\text { [11] }\end{array}$ \\
\hline HPLC-UV & Tap water, River water & $0.2-5 \mu \mathrm{g} \cdot \mathrm{L}^{-1}$ & $0.06 \mu \mathrm{g} \cdot \mathrm{L}^{-1}$ & $\begin{array}{l}\text { H. Bagheri et al., } 2004 . \\
\text { [12] }\end{array}$ \\
\hline HPLC-FD & Human urine & $0.5-50 \mathrm{mg} \cdot \mathrm{L}^{-1}$ & $0.05 \mathrm{mg} \cdot \mathrm{L}^{-1}$ & $\begin{array}{l}\text { G. Marrubini et al., } \\
\text { 2005. [13] }\end{array}$ \\
\hline HPLC-UV & Bambo pulp & $0.01-10 \mathrm{mg} \cdot \mathrm{L}^{-1}$ & $1.5 \mu \mathrm{g} \cdot \mathrm{L}^{-1}$ & $\begin{array}{l}\text { N. Sharma et al., } 2011 . \\
\text { [14] }\end{array}$ \\
\hline HPLC-UV & River water, Tap water & $100-500 \mathrm{ng} \cdot \mathrm{L}^{-1}$ & $82.1 \mathrm{ng} . \mathrm{L}^{-1}$ & $\begin{array}{l}\text { M. C. Alcudia et al., } \\
\text { 2011. [15] }\end{array}$ \\
\hline HPLC-UV & Rice wines & $0.5-50 \mu \mathrm{g} . \mathrm{L}^{-1}$ & $0.02 \mu \mathrm{g} \cdot \mathrm{L}^{-1}$ & $\begin{array}{l}\text { Y. Huang et al., } 2015 . \\
\text { [16] }\end{array}$ \\
\hline HPLC-UV & $\begin{array}{l}\text { Soil extract, Sea water, } \\
\text { River water, Tap water, } \\
\text { Ground water }\end{array}$ & $1.2-11.6 \mu \mathrm{g} . \mathrm{L}^{-1}$ & $0.5 \mu \mathrm{g} \cdot \mathrm{L}^{-1}$ & $\begin{array}{l}\text { R. G. Dolatto et al., } \\
\text { 2016. [17] }\end{array}$ \\
\hline HPLC-UV & $\begin{array}{l}\text { Tap water, Stream wa- } \\
\text { ter, Dam lake water }\end{array}$ & $2-300 \mu \mathrm{g} \cdot \mathrm{L}^{-1}$ & $0.07 \mu \mathrm{g} \cdot \mathrm{L}^{-1}$ & This work \\
\hline
\end{tabular}

\section{CONCLUSION}

We have developed a pre-column RP-HPLC UVvisible method for simultaneous determination of phenol, $\mathrm{m}$-cresol and resorcinol in water by using 4-aminoantipyrine as a labeling reagent, without complicated sample cleanup. The results showed that this new method was simple, rapid, practicable and feasible with high precision, sensitivity and repeatability, and could also provide a good resolution of the phenolic compounds in water samples. Thus, this procedure can be used to determine the basic phenolic compounds in various type of environmental samples.

\section{ACKNOWLEDGEMENT}

The authors are grateful for the financial support of the scientific Research projects of Ondokuz Mayis University (project no. PYO.FEN.1904.11.021). 


\section{References}

1. M.L. Soto, A. Moure, H. Domínguez, J.C. Parajó, Recovery, concentration and purification of phenolic compounds by adsorption: a review, J. Food Eng., 105 (2011) 1-27.

2. A. Penalver, E. Pocurrull, F. Borrull, R.M. Marce, Solidphase microextraction coupled to high-performance liguid chromatography to determine phenolic compounds in water samples, J. Chromatogr. A, 953 (2002) 79-87.

3. H. Xu, Y. Liao, J. Yao, Development of a novel ultrasound-assisted head-space liquid-phase microextraction and its application to the analysis of chlorophenols in real aqueous samples, J. Chromatogr. A, 1167 (2007) 1-8.

4. EPA. Methad 604, Phenols, Part VIII, 40 CFR part 136. US Environmental Protection Agecy, 26 july 2014.

5. M. L. Barrico, C. Nabais, M.J. Martins, H. Freitas, Sources of phenolic compounds in two catchments of southern Potugal-effect of season, land use and soil type, Chemosphere, 65 (2006) 482-488.

6. A.R. Sousa, M.A. Trancoso, Validation of an environmental friendly segmented flow method for the determination of phenol index in waters as alternative to the conventional one, Talanta, 79 (2009) 769-803.

7. S. Lacorte, A. Latorre, D. Barcelo, A. Rigol, A. Malmiqvist, T. Welander, Organic compounds in papwer-mill process waters and effluents, Trends Anal. Chem., 22 (2003) 725-737.

8. J. Michalowich, W. Duda, Phenols-sources and toxicity, Pol. J. Environ. Stud., 16 (2007) 347-362.

9. K.O. Lupetti, F.R.P. Rocha, O. Fatibello-Filho, An immproved flow system for phenols determination explieting multicommutation and long pathlength spectrophotometry, Talanta, 62 (2004) 463-469.

10. A. Asan, I. Isildak, Determination of major phenolic compounds in water by reversed-phase liquid chromatography after pre-column derivatization with benzoyl chloride. J. Chromatogr. A, 988 (2003) 145 149.

11. L. Zhao, K.H. Lee, Determination of phenols in water using.Liquid phase microextraction with back extraction combined with high-prformance liquid chromatography, J. Chromatogr. A, 931 (2001) 95-105.

12. H. Bagheri, A. Mohammadi, A. Salemi, On-line trace enrichment of phenolic compounds from water using a pyrrole-based polymer as the solid-phase extraction sorbent coupled with high-performance liquid chromatography, Anal. Chim. Acta, 513 (2004) 445-449.

13. G. Marrubini, E. Calleri, T. Coccini, A.F. Castoldi, L. Manzo, Direct analysis of phenol, catechol and hydroquinone in human urine by coupled-column HPLC with fluorimetric detection, Chromatographia, 62 (2005) 25-31.

14. N. Sharma, A. Jain, V. Kumari Singh, K.K. Verma, Solid-phase extraction combined with headspace single-drop microextraction of chlorophenols as their methyl ethers and analysis by high-performance liquid chromatography-diode array detection, Talanta, 83 (2011) 994-999.
15. M.C. Alcudia-León, R. Lucena, S. Cárdenas, M. Valcárcel. Determination of phenols in waters by stir membrane liquid-liquid-liquid micro extraction coupled to liquid chromatography with ultraviolet detection, J. Chromatogr. A, 1218 (2011) 2176-2181.

16. Y. Huang, W.W. Lu, B. Chen, M. Wu, S.G. Li, Determination of 13 phenolic compounds in rice wine by high-performance liquid chromatography, Food Anal. Methods, 8 (2015) 825-832.

17. R.G. Dolatto, I. Messerschmidt, B.F. Pereira, R. Martinazzo, G. Abate, Preconcentration of polar phenolic compounds from water samples and soil extract by liquid-phase micro extraction and determination via liquid chromatography with ultraviolet detection, Talanta, 148 (2016) 292-300.

18. L. Montero, S. Conradi, H. Weiss, P. Popp, Determination of phenols in lake and ground water samples by stir bar sorptive extraction-thermal desorption-gas chromatography-mass spectrometry, J. Chromatogr. A, 1071 (2005) 163-169.

19. H. Faraji, M.S.Tehrani, S.W. Husain, Pre-concentration of phenolic compounds in water samples by novel liquid-liquid microextraction and determination by gas chromatography-mass spectrometry, J. Chromatogr. A, 1216 (2009) 8569-8574.

20. J.A. Padilla-Sánces, P. Plaza-Bolaños, R. RomeroGonzález, N. Barco-Bonilla, J.L. Martínez-Vidal, A. Garrido-Frenich, Simultaneous analysis of chlorophenols, alkylphenols, nitrophenols and cresols in wastewater effluents, using solid phase extraction and further determination by gas chromatographytandem mass spectrometry, Talanta, 85 (2011) 23972404.

21. H. Ghorbanpour, A. Yadeghari, L. Khoshmaram, M.A. Farajzadeh, Air-assisted liquid-liquid microextraction for simultaneous derivatization, extraction, and preconcentration of some phenolic compounds. Anal. Methods, 6 (2014) 7733-7743.

22. Y.C. Fiamegos, A-P. Kefala, C.D. Stalikas, Ion-pair single-drop microextraction versus phase-transfer catalytic extraction for the gas chromatographic determination of phenols as tosylated derivatives, J. Chromatogr. A, 1190 (2009) 44-51.

23. E.L.B. Lourenço, A. Ferreira, E. Pinto, M. Yonamine, S.H.P. Farsky, On-fiber derivatization of SPME extracts of phenol, hydroquinone and catechol with GC-MS detection, Chromatographia, 62 (2006) 175179.

24. W. Wei, X. Yin, X. He, pH-mediated dual-cloud point extraction as a preconcentration and clean-up technique for capillary electrophoresis determination of phenol and m-nitrophenol, J. Chromatogr. A, 1202 (2008) 212-215.

25. T. Li, Q. Jia, L. Song, R. Su, Y. Lei, W. Zhou, H. Li, Coupling poly-(methacrylic acid-co-ethylene glycol dimethacrylate) monolith micro extraction to capillary electrophoresis for the determination of phenols in water samples. Talanta, 78 (2009) 1497-1502.

26. L. Zhu, H.K. Ee., L. Zhao, H.K. Lee, Analysis of phenoxy herbicides in bovine milk by means of liquid-liquid micro extraction with a hollow-fiber membrane. J. Chromatogr. A, 963 (2002) 335-343. 
27. W.L. Chen, G.S. Wang, J.C. Gwo, C.Y. Chen, Ultra-high performance liquid chromatography/tandem mass spectrometry determination of feminizing chemicals in river water, sediment and tissue pretreated using disk-type solid-phase extraction and matrix solid phase dispersion, Talanta, 89 (2012) 237-245.

28. E. Morita, E. Nakamura, Solid-phase extraction of antipyrine dye for spectrophotometric determination of phenolic compounds in water, Anal. Sci., 27 (2011) 489-492.
29. S.R. Tambe, R.H. Shinde, L.R. Gupta, V. Pareek, S.B. Bhalerao, Development of Ile and spe procedures and its applications for determination of olmesartan in human plasma using RP-HPLC and HPTLC. J. Liq. Chromatogr. Relat. Technol., 33 (2010) 423-430.

30. Topic Q2A, Validation of analytical Procedures, Methodology, International Conference

on Harmonization, Brussels, Belgium, 1995.

31. C.M. Riley, T.W. Rosanske, Development and validation analytical methods, Amsterdam: Elsevier, 1996. 